\title{
Teacher motivation in stricto sensu postgraduation: an analysis based on self-determination theory ${ }^{\star, * *}$
}

\author{
Ana Carolina Vasconcelos Colares ${ }^{1,2}$ \\ (D) https://orcid.org/0000-0001-8317-752X \\ Email: carolinacolares@pucminas.br
}

Mariana Camilla Coelho Silva Castro²,3
(D) https://orcid.org/0000-0001-9174-9786
Email: marianac@reitoria.ufmg.br

João Estevão Barbosa Neto ${ }^{2}$

(D) https://orcid.org/0000-0001-5197-2166

Email: joaoestevaobn@face.ufmg.br

\author{
Jacqueline Veneroso Alves da Cunha ${ }^{2}$ \\ (D) https://orcid.org/0000-0003-2522-3035 \\ Email: jvac@face.ufmg.br
}

${ }^{1}$ Pontifícia Universidade Católica de Minas Gerais, Instituto de Ciências Gerenciais, Belo Horizonte, MG, Brazil

${ }^{2}$ Universidade Federal de Minas Gerais, Faculdade de Ciências Econômicas, Departamento de Ciências Contábeis, Belo Horizonte, MG, Brazil

${ }^{3}$ Universidade Federal de Juiz de Fora, Faculdade de Administração e Ciências Contábeis, Departamento de Finanças e Controladoria, Juiz de

Fora, MG, Brazil

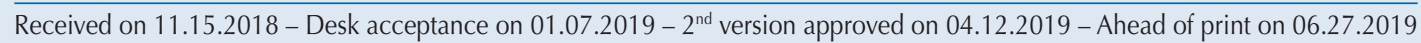

Ad Hoc Associate Editor: Gilberto José Miranda

\begin{abstract}
The objective of this research was to analyze the motivational factors that lead accounting sciences professors to teach on stricto sensu postgraduate courses, based on self-determination theory. Research on motivation in education in the area of accounting sciences mostly concerns student motivation. Thus, there are few studies related to teacher motivation, especially in the area of accounting sciences and in stricto sensu postgraduate programs. Teacher motivation is directly linked to the teaching-learning process and student motivation, so it is important to identify what motivates these teachers and, given this, to act in a way that the motivation, or lack of it, will not interfere with the quality of teaching. The importance of teachers in the quality of education is indisputable and inevitably relates to the motivation to remain in the teaching career, taking both personal and professional aspects into account. The Work Tasks Motivation Scale for Teachers was applied and answered by 108 professors from the 33 stricto sensu postgraduate programs in the area of accounting sciences. The data were analyzed in an aggregated way, using descriptive statistics and Wilcoxon-Mann-Whitney and chi-squared tests, with the purpose of assessing the relationship between levels of motivation and age group, time teaching, and time teaching in the stricto sensu postgraduate course. Most of the professors analyzed are extrinsically motivated via identified regulation; however this is less related to access to financial resources and more linked to the prestige that teaching on the stricto sensu postgraduate course brings. Also, the overall mean of the dimensions of intrinsic and extrinsic motivation was shown to be higher for teachers of the female gender and who work in private institutions.
\end{abstract}

Keywords: motivation, self-determination theory, stricto sensu postgraduation, accounting sciences, teacher motivation.

\section{Correspondence address}

Ana Carolina Vasconcelos Colares

Pontifícia Universidade Católica de Minas Gerais, Departamento de Ciências Contábeis

Rua Walter lanni, 255, Bloco H - CEP 31980-110

São Gabriel - Belo Horizonte - MG - Brazil

*Paper presented at the VI Teaching and Research Conference in Business Administration and Accounting - EnEPQ, Porto Alegre, RS, Brazil, May 2018.

**The authors are grateful to the National Council for Scientific and Technological Development (CNPq) for its financial support to carry out this research. 


\section{INTRODUCTION}

Teachers perform duties that go beyond classroom teaching, and this reality has an effect on their satisfaction and motivation, with consequences for themselves and their educational work (Larocca \& Girardi, 2011). Thus, an important debate arises regarding the factors that motivate teachers in their professional endeavors over the years. This discussion has been widespread in areas such as music, physical education, psychology, and chemistry (Cernev, 2011; França, Rodrigues, Mariano Júnior \& Campos, 2012; Sá \& Santos, 2016). However, there is no consensus as to whether the motivational factors determine the way these professionals carry out their activities in an expressive and effective way.

According to Herdeiro and Silva (2014), the motivation of teachers appears to be at the heart of the question of quality of teaching and of teacher training, along with their satisfaction and professional fulfillment. Davoglio, Santos, and Spagnolo (2017) also understand that the importance of teachers in the quality of education is indisputable and inevitably relates to the motivation to remain in the teaching career, taking both personal and professional aspects into account. According to Huberman (1989), over the course of their careers, teachers tend to reduce their commitment and self-efficacy in relation to teaching. Iaochite, Costa Filho, Matos, and Sachimbombo (2016) define self-efficacy in teaching as the judgement that teachers make regarding their abilities to teach. It is related to the way teachers view their profession; those with stronger self-efficacy beliefs are more satisfied and present higher levels of motivation to teach.

In a study carried out on 43 professors of a postgraduate course in accounting sciences in the state of Santa Catarina, Silva, Pletsh, and Biavatti (2015) observed that the main reasons these professors practice the profession are: love for the career; teaching and research; interpersonal relationships; career plan; personal and professional satisfaction; working at a university; financial; among others. And the causes of their motivation when performing this activity are linked to their relationship with work colleagues and students, personal effort, and luck.

Ryan and Deci (2000a) question whether the studies that address motivation are based on theories that treat motivation as a unique phenomenon, varying between much and little motivation. However, the authors suggest that motivation is unlikely to be a unique phenomenon, with there being, besides levels, different motivation types.

In this context, Ryan and Deci (2000b) developed selfdetermination theory, which considers that motivation for work has two dimensions: intrinsic motivation and extrinsic motivation. For Deci (1971), intrinsically motivated activities are characterized as not having any apparent reward beyond the activity itself. Extrinsic motivation can be defined as a behavior that leads the individual to perform an activity envisioning rewards, with a view towards the results more than the activity itself (Pizani, Barbosa-Rinaldi \& Miranda, 2016).

Studies on motivation in education in the area of accounting sciences mostly concern student motivation (Borges, Miranda \& Freitas, 2017; Durso, Cunha, Neves \& Teixeira, 2016; Leal, Miranda \& Carmo, 2013). The results of these studies show that the student's motivation is linked to motivational aspects of the teachers. Therefore, many of the learning difficulties found by students in the accounting area can be related to the communication process and to the teacher's motivational process. For Guimarães and Boruchovitch (2004), the teacher's motivational style is vulnerable to sociocontextual factors, such as the number of students in the classroom, time of experience teaching, gender, and age, among others, as well as his/her own personality. However, if teachers do not find the motivation to carry out their activities, they will be unable to motivate their students to obtain better results.

One of the consequences of a lack of student motivation, as observed in the studies by Biazus (2004), Bizarria, Carneiro, Silva, and Tassigny, (2016), and Leal et al. (2013), is evasion. In a study regarding the factors that influence the evasion of accounting sciences courses, Biazus (2004) observed that the main didactic-pedagogical component is the low motivation of teachers.

There are few studies related to teacher motivation, especially in the area of accounting sciences (Silva et al., 2015). For Barreto and Martinez (2007), making educational practice and academic guidance a creative and innovative teaching-learning process for professors of stricto sensu postgraduate courses strongly involves motivation.

Since teacher motivation is directly linked to the teaching-learning process and to student motivation, and taking into account that the professors who teach on stricto sensu postgraduate courses are responsible for training future teachers and professionals in the area of accounting, it is important to identify what motivates these professors to perform and, given this, act in a way that their motivation, or lack of it, does not interfere with the quality of teaching. Thus, this study intends to 
answer the following question: what motivational factors lead professors in the area of accounting sciences to teach on stricto sensu postgraduate courses, in light of selfdetermination theory? From this perspective, the general aim of this research is to identify the motivational factors that lead professors in the area of accounting sciences at Brazilian universities to teach in stricto sensu postgraduate programs.

The importance of the research is related to the perception of how much the teacher's motivation can influence the teaching and learning process, since the greater the teacher's motivation, the greater the chances of the students learning. Therefore, studies focused on evaluating the teacher's motivational quality could provide promising alternatives for the educational area (Rudnik, 2012). As an applied justification, the study could serve as a basis on which those responsible for postgraduate programs in accounting could formulate instruments that could motivate the teacher, such as the creation of a motivation project. It is important that, in these programs, actions are implemented to incentivize teachers to work enthusiastically and willingly inside and outside the classroom, contributing to the teaching and research quality. This study constitutes a tool that could also help professors themselves to improve their motivation in relation to carrying out postgraduation activities.

Academically, the research is relevant in so much as it provides a picture of the motivational profile of the professors, enabling the development of motivation strategies based on this panorama. In addition, it aims to broaden the study on motivation, by comparing professors from public and private teaching institutions, thus with different incentives for teaching in stricto sensu postgraduation, specifically in the area of accounting sciences.

\section{THEORETICAL FRAMEWORK}

\subsection{Self-Determination Theory}

Motivation is a central and persistent issue in the field of psychology, since it lies at the heart of biological, cognitive, and social questions. It has been evaluated extensively due to the consequences that it produces, and is therefore important for individuals who carry out functions related to mobilizing other individuals to act, such as managers, teachers, religious leaders, trainers, doctors, and parents (Ryan \& Deci, 2000a).

The study of motivation represents the search for explanations for human behavior and has developed rapidly in recent decades. Motivation is not something that can be directly observed; the existence of motivation is inferred by observing behavior, which can be the result of various motives acting at the same time.

Another aspect related to motivation concerns the teacher life cycle. For Huberman (1989), the individual behaviors of teachers are fundamental pieces for continuation in the career. There are five different stages into which the author categorizes the professional life cycle: from zero to three years (entry into the career); from four to six years (stabilization phase); from seven to 25 years (diversification phase); from 25 to 35 years (serenity phase); and from 35 to 40 years (divestment phase). Huberman (1989) relates time of career with the behavior developed by the teacher to define the stages of the teacher life cycle. Thus, the author highlights that teachers have different interests and motivations over the course of their careers.

For Ryan and Deci (2000a), most of the theories view motivation as a unique phenomenon, which varies between abundant and scarce. However, motivation is unlikely to be a unique phenomenon; people not only have different quantities (much or little motivation), but also different types of motivation. The motivational orientation concerns the attitudes and goals that give rise to the actions, to the reason for the actions.

There are different theories that address motivation, among which self-determination theory (SDT) stands out, which considers that motivation can cause effects on the individual's behavior and that these consequences can interfere with motivation (Borges et al., 2017).

In self-determination theory, distinctions are made based on the reasons or objectives that give rise to action among different types of motivation. The most basic distinction is between intrinsic motivation, which relates to doing something because it is inherently interesting, and extrinsic motivation, which relates to doing something expecting a result (Ryan \& Deci, 2000a).

Pizani et al. (2016) mention that, based on selfdetermination theory, Deci and Ryan (1985) established motivation as being continuous and characterized by levels of self-determination. With this, motivational behaviors 
can be understood based on a continuum that lies between the low level of self-determination (demotivation) and the high level (extrinsic and intrinsic motivation).

Intrinsic motivation arises as an important phenomenon for educators, a natural source of learning and fulfillment that can be systematically catalyzed or mined through the practices of parents and teachers (Ryan \& Deci, 2000a). For Deci (1971), intrinsically motivated activities are characterized as not having any apparent reward beyond the activity itself, which leads to the conclusion that intrinsic motivation is associated with personal fulfilment or the work itself. Although intrinsic motivation is clearly an important type of motivation, according to Ryan and Deci (2000a), most activities that people perform are not, strictly speaking, intrinsically motivated.

Extrinsic rewards are those in which the variables that trigger the behavior are perfectly identified and are provided by the environment, such as salaries and other monetary benefits, a reduction in workload, promotions, etc., and result in extrinsic motivation because they provide satisfaction independently of the task itself and are beyond the control of the individual him/herself (Lira \& Silva, 2015).

With relation to extrinsic motivation, if the rewards that the individual seeks by developing his/her activities were removed, the motivation would decrease. This would reveal that involvement in the activity occurs with some purpose in mind, without the presence of any intrinsic interest. This motivational behavior consists of a varied set of behaviors, meaning that there are different types of regulation of the motivation: integrated, identified, introjected, and external (Pizani et al., 2016). Figure 1 shows the taxonomy of the motivation types presented by Ryan and Deci (2000a), organized from left to right in relation to the level of motivation for the individual's behavior.

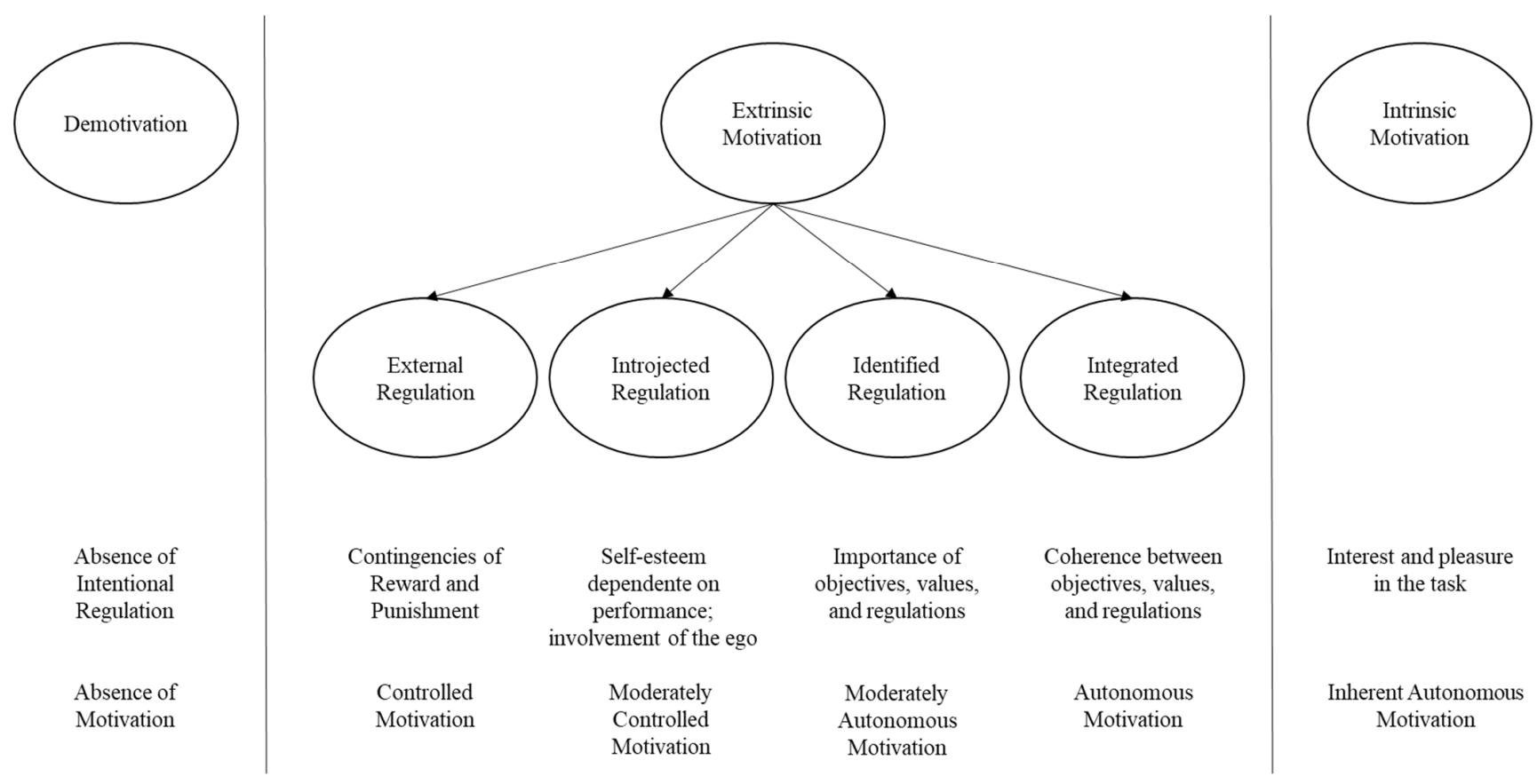

Figure 1 Self-determination continuum

Source: Leal, Miranda, and Carmo (2013, p. 164).

In Figure 1, at the far left, is demotivation, which is the state of a lack of willingness to act. When demotivated, a person's behavior lacks intentionality and a sense of personal causality (Ryan \& Deci, 2000a). Demotivation refers to behaviors that reflect a lack of intentionality and are not driven by extrinsic motivation or by intrinsic motivation. On the motivation continuum, demotivation has the lowest level of autonomy, and demotivated individuals do not act or act without intention or motivation. In self-determination theory, demotivation is characterized by an absence of self-determination, represented by a deficiency of intention, a lack of control over the activities, and insufficient proactivity (Bizarria et al., 2016).

To the right of demotivation is the category that represents less autonomous forms of motivation, extrinsic motivation, divided into four subcategories: external regulation, introjected regulation, identified regulation, and integrated regulation. In this case, when carrying out a task, the individual seeks an external reward (Figure 1). 
According to Deci and Ryan (1985), extrinsic motivation is ordered, with external regulation being the least autonomous and integrated regulation being the most autonomous. External regulation is a behavior that is carried out to satisfy an external demand or obtain external rewards. According to Machado, Guimarães, and Bzuneck (2006), in external regulation, the person focuses only on the benefits derived from the situation. One example that the authors provide is when a child makes his/her bed in order to be able to watch television. His/her attention is focused on the benefit derived, and not on the process of making the bed.

A second type of extrinsic motivation is introjected regulation, which describes a type of internal regulation that is still relatively controllable, since people carry out such actions under a feeling of pressure to avoid guilt or anxiety or, also, to maintain or improve their self-esteem, sense of value, or ego. Although the regulation is internal to the person, the behaviors are not experienced as an integral part of oneself (Ryan \& Deci, 2000a).

According to Ryan and Deci (2000a), one form of extrinsic motivation that is a little more autonomous or self-determined is regulation via identification. In this, the person identifies with the importance of a behavior and accepts the regulation as if it were his/hers. According to Leal et al. (2013), identified regulation is the most autonomous type compared to the previous ones, since in this situation there is already some interiorization by the person, even if his/her reason for doing something is external in origin. The authors mention as an example when a student makes an effort at school, thinking of becoming an architect one day. Although this motivation is extrinsic, it is the one that identifies with the reason for the student to study.

For Machado et al. (2006, p. 8), "in identified regulation, the individual feels a personal attraction towards a particular behavior or towards people that present it and believe in him/her. This level is a little more stable and the resulting behavior is not yet autonomous, but the initial interest is." The most autonomous form of extrinsic motivation is integrated regulation, which occurs when the identified regulations are totally assimilated. This occurs via self-examination, providing new regulations that are consistent with other values and needs (Ryan \& Deci, 2000a).

Finally, the most self-determined type of motivation is intrinsic motivation. According to Borges et al. (2017), this arises when a particular activity is carried out for the individual's own satisfaction; that is, a student studies because he/she feels pleasure when studying. Thus, the conclusion of this activity is considered to be spontaneous, and there is no need for external or internal pressures for it to be carried out. Therefore, self-determination theory is an important tool for understanding how social agents and environments influence the individual's motivation. Ryan and Deci (2000a) consider that, by knowing these needs, people can predict the behavioral effects over their motivation. For Cernev (2011), when a teacher experiences healthy development and positive emotions in his/her work environment, these provide and contribute to the satisfaction of his/her psychological needs.

\subsection{Previous Studies}

Self-determination theory has been the basis for various studies, among which the study carried out by Vallerand et al. (1992) stands out, which aimed to validate an instrument for evaluating motivation patterns using an assessment scale for measuring motivation for education (Echelle de Motivation en Education - EME), constituted by Vallerand, Blais, Brière, and Pelletier (1989), using 746 higher education students as research subjects. The EME is based on the concept of intrinsic motivation, extrinsic motivation, and demotivation, in accordance with selfdetermination theory. The results showed that the EME revealed robust psychometric properties, reinforcing the validity of the instrument.

In Brazil, this scale was initially used by Sobral (2003). His research aimed to analyze the characteristics of the motivation of medical students and its relationship with academic factors at the beginning of the course, based on self-determination theory. His results showed a predominance of autonomous motivation and sexual variation. The correlations between components of the Academic Motivation Scale (AMS) and predecessors and motivational consequences revealed motivation to be related with individual and contextual questions. The results show that there is validity in the instrument, as well as in its application to university motivation. Based on the research of Sobral (2003) and the validation of the instrument, studies have been carried out using the AMS, including the studies by Leal et al. (2013) and Durso et al. (2016).

Leal et al. (2013) evaluated the motivation of accounting sciences students at a Brazilian public university in light of self-determination theory. The research was conducted using 259 accounting sciences students, revealing that the students researched presented a self-determined motivation profile. Indications were also observed that accounting sciences students have a lower level of intrinsic motivation that those of other courses, and that new students present a higher level of autonomous 
motivation, while concluding students present a higher level of extrinsic motivation.

Durso et al. (2016) analyzed the motivational level of accounting sciences and economic sciences students with relation to the search for a stricto sensu postgraduation to determine the variables that influence their motivation. Based on self-determination theory, they applied a questionnaire to 173 university students from public institutions in the state of the Minas Gerais. The results revealed that the accounting sciences students do not present any difference in motivational level when compared with the economic sciences students. They also found that the women, the oldest, those with a scientific initiation scholarship, those from lower socioeconomic classes, and those whose mothers are more highly educated tend to present more self-determined motivation.

By researching studies that have used self-determination theory as a base theory, it can be identified that most of the studies sought to analyze motivation related to students, using the AMS as a data collection instrument, thus leaving a gap in relation to verifying teacher motivation.

From this perspective, based on the research by Vallerand et al. (1992), Fernet, Senécal, Guay, Marsh, and Dowson (2008) developed a study specifically addressing the evaluation of teacher motivation. The authors suggested that, in general, studies that address motivation do not take into account the complexity and variation of self-perceptions that can hamper the ability to understand and predict behaviors. In light of this, the study sought to develop and validate a tool for measuring the motivation of teachers in relation to their activities. The study covered two objectives, the first being to develop items to evaluate intrinsic motivation, identified, introjected, and external regulation, and demotivation for six tasks carried out by teachers, such as class preparation, teaching, student evaluation, course management, and complementary tasks. The instrument used was The Work Tasks Motivation Scale for Teachers (WTMST). The second objective was to verify the validity of the WTMST, which encompassed five tests.

In general, the results revealed that the WTMST is composed of 30 reliable and valid factors that reflect the five motivation types. The authors concluded that the approach can be used as a support for evaluating the motivation of teachers for their activities in light of selfdetermination theory.

In Brazil, Rudnik (2012) analyzed the WTMST with the aim of adapting and validating a Brazilian version of the instrument, based on self-determination theory. Besides the items from the original scale, the author added others, based on the literature and suggestions from the interviewees. The questionnaire was applied to 500 teachers from the public and private sector. According to the results, there was consistency with self-determination theory, since a greater correlation was found between the closest and smallest factors at the extreme points. The evidence enabled it to be considered valid for research on teacher motivation.

Given the studies by Fernet et al. (2008) and Rudnik (2012), which validated the WTMST as an instrument for analyzing teacher motivation, this was used in this study to analyze the type of motivation that leads professors affiliated with courses in the area of accounting sciences at Brazilian universities to teach in stricto sensu postgraduation programs, in light of self-determination theory.

\section{METHODOLOGICAL PROCEDURES}

\subsection{Classification of the Research}

This study, which is descriptive in nature, used a survey as its procedure, applying the WTMST instrument, from Fernet et al. (2008). Regarding the approach, the research is of a quantitative and qualitative nature, and applies descriptive statistics in relation to the analysis of the data and of the profile of the individuals in the sample. It also sought to identify statistically relevant differences between the groups identified by the variables analyzed, such as gender and type of institution with which the professor is affiliated. For the qualitative approach, an open question was included in the questionnaire, aiming to identify in more depth the possible additional motivations.

\subsection{Study Universe and Sample}

In order to form the sample for the study, 33 stricto sensu postgraduation programs in accounting in Brazil were identified, via the Coordination for the Improvement of Higher Education Personnel (Capes) website, with the consultation being carried out in August of 2018. This included the courses in Business Administration and Controlling at the Federal University of Ceará, of Controlling at the Rural Federal University of Pernambuco, and of Controlling and Corporate Finance at the Mackenzie Presbyterian University, since they presented an accounting approach in accordance with their course programs. 
After selecting the programs, searches were carried out on the webpages of each one of the courses in order to identify the professors participating in the programs and their email addresses to send the questionnaire. Initially, 443 professors were identified. However, it was found that some professionals taught in more than one postgraduation program and these duplicities were eliminated, leaving 411 professors. The questionnaires were sent via email, using a form available on Google Docs, which has the advantages of lower cost and greater speed in obtaining the answers (Martins \& Theophilo, 2009). After contacting the professors, 108 answers were obtained, which composed the final non-probabilistic study sample.

With relation to the institutions that have stricto sensu postgraduation courses in accounting in Brazil, 29 institutions were identified, with the Capixaba Foundation Institute of Research in Accounting, Economics, and Finance (Fucape) having three postgraduate programs in accounting: one academic and one professional in the state of Espírito Santo and a professional one in the state of Rio de Janeiro. The Federal University of Ceará has one academic program and one professional. The University of Brasilia (UnB) has a program in Brasilia and another interinstitutional one [UnB - Federal University of Paraíba (UFPB) - Federal University of Rio Grande do Norte (UFRN)], as observed on the webpage of the Coordination for the Improvement of Higher Education Personnel (Capes, 2017), totaling 33 programs.

The average rate of response to the questionnaire was $26 \%$. The highest response rate was observed for the State University of Maringá (UEM) (80\%), followed by the Federal University of Rio Grande (FURG) (75\%), the Community University of the Chapecó Region (Unochapecó), and the Federal University of Minas Gerais (UFMG) (54\%).

\subsection{Data Collection Instrument}

For the data collection, a structured electronic questionnaire with closed questions and one open question was used. In this research, 7-point numerical agreement scales were used, in accordance with the Work Tasks Motivation Scale for Teachers (WTMST), from Fernet et al. (2008), which provides support in light of self-determination theory to evaluate the motivation of teachers in their tasks.

Self-determination theory postulates the existence of three broad types of motivation, characterized by different levels of self-determination, as according to Table 1 .

\section{Table 1}

Dimensions of the Work Tasks Motivation Scale for Teachers (WTMST)

\begin{tabular}{|c|c|}
\hline Dimension & Description \\
\hline Intrinsic motivation & Involves the pleasure or satisfaction derived from carrying it out. \\
\hline Identified regulation & $\begin{array}{l}\text { Defined as the behavior that individuals choose to display because it is coherent with their own values and } \\
\text { objectives. Instead of succumbing to external or internal pressures, individuals experience the choice by doing the } \\
\text { activity, although the activity is not intrinsically interesting. }\end{array}$ \\
\hline Introjected regulation & $\begin{array}{l}\text { Corresponds to the process through which an external demand becomes an internal representation. Individuals } \\
\text { experience pressure through internal coercion (for example, anxiety, shame, or guilt) to certify that a specific } \\
\text { behavior is carried out. }\end{array}$ \\
\hline External regulation & Occurs when the behaviors are regulated to obtain a reward or to avoid a restriction. \\
\hline Demotivation & $\begin{array}{l}\text { Demotivation corresponds to the lowest level of self-determination. Individuals are demotivated when they are } \\
\text { unwilling to engage in a particular behavior, and do not really know why they are doing it. }\end{array}$ \\
\hline
\end{tabular}

Source: Fernet, Senécal, Guay, Marsh, and Dowson (2008).

The questionnaire used in the research covered 15 items (three in relation to each one of the motivation dimensions), answered by the professors, aiming to evaluate, via the agreement scale, which dimension would best classify the motivation to perform their activities, between intrinsic motivation, regulation through identification, regulation through introjection, external regulation, or demotivation.

Besides the items addressed in the WTMST, questions were included that enabled the profile of the studied sample to be known, as well as creating categories for analysis, reflecting age, gender, affiliated program, time teaching, and time teaching in postgraduation programs. After the questions related to the WTMST, four items were elaborated on the 7-point Likert-type agreement scale that reflected the feeling of the professors regarding the obtainment of status and of financial resources by carrying out the task of teaching in a stricto sensu postgraduation program. Finally, an open question was elaborated so that the professors could share, besides the alternatives 
mentioned on the scale, other reasons that could motivate their performance in the stricto sensu postgraduation of the institution where they work.

\subsection{Data Treatment and Research Hypotheses}

With relation to the data treatment, initially the normality test was carried out to determine what type of statistical test would be employed. From the options for verifying whether a distribution is normal, the ShapiroWilk test was carried out. Based on this test, it was verified that the gender and institution type variables did not have a normal distribution.

As in the study by Fernet et al. (2008), the possible effects of gender were explored, since other studies have demonstrated that, typically, women present higher levels of intrinsic and identified regulation in relation to work than men (Vallerand et al., 1992). Besides gender, the type of institution with which the professor is affiliated was also analyzed, using the Wilcoxon-Mann-Whitney non-parametric test for identifying statistically significant differences between the variables of the groups analyzed, aiming to describe a behavior or perception of the users given these characteristics.

The chi-squared test was also applied with the aim of analyzing the relationship between the levels of motivation and age group, time teaching, and time teaching in stricto sensu postgraduation. Thus, the following working hypotheses were proposed:

$\mathrm{H}_{1}$ : there is a difference in motivation between female and male teachers;

$\mathrm{H}_{2}$ : there is a difference in motivation between teachers from public institutions and private institutions;

$\mathrm{H}_{3}$ : there is a relationship between teacher motivation and their age group;

$\mathrm{H}_{4}$ : there is a relationship between teacher motivation and time teaching;

$\mathrm{H}_{5}$ : there is a relationship between teacher motivation and time teaching in stricto-sensu postgraduation.

\section{RESEARCH RESULTS}

First, Table 2 presents the profile of the survey respondents using sociodemographic variables. The sample was composed of 108 professors teaching in stricto sensu postgraduation programs in the area of accounting in Brazil.

Table 2

Profile of the respondents

\begin{tabular}{|c|c|c|c|c|c|}
\hline Gender & Quantity (n) & $\%$ & Institution type & Quantity (n) & $\%$ \\
\hline Female & 31 & 29.0 & Public & 93 & 86.1 \\
\hline Male & 76 & 71.0 & Private & 15 & 13.9 \\
\hline Did not answer & 1 & & & & \\
\hline Age group & Quantity (n) & $\%$ & & & \\
\hline Up to 30 & 3 & 2.8 & & & \\
\hline $31-40$ & 22 & 20.4 & & & \\
\hline $41-50$ & 48 & 44.4 & & & \\
\hline $51-60$ & 22 & 20.4 & & & \\
\hline More than 60 & 13 & 12.0 & & & \\
\hline Time teaching (years) & Quantity (n) & $\%$ & $\begin{array}{c}\text { Time in stricto sensu } \\
\text { postgraduation (years) }\end{array}$ & Quantity (n) & $\%$ \\
\hline Up to 5 & 3 & 2.8 & Up to 5 & 59 & 54.6 \\
\hline $6-10$ & 18 & 16.7 & $6-10$ & 22 & 20.4 \\
\hline $11-15$ & 26 & 24.1 & $11-15$ & 13 & 12.0 \\
\hline $16-20$ & 26 & 24.1 & $16-20$ & 9 & 8.3 \\
\hline $21-25$ & 12 & 11.1 & $21-25$ & 1 & 0.9 \\
\hline More than 25 & 23 & 21.3 & More than 25 & 4 & 3.7 \\
\hline
\end{tabular}

Source: Elaborated by the authors using data from the research (2018). 
Based on the data presented, it is possible to verify that most of the professors in the study are men (71\%), working in the public teaching sector (86.1\%), and belonging to the 41-50 age group. According to Huberman (1989), over the course of their teaching careers, teachers have different stages with different interests and motivations. The author classifies the professional life cycle into five different phases: entry into the career (zero to three years); stabilization phase (four to six years); diversification phase (seven to 25 years); serenity phase ( 25 to 35 years); and divestment phase ( 35 to 40 years). Most of the professors researched (64.3\% between 11 and 25 years) are in the diversification phase of their careers, and so may be seeking to work in other areas, such as in stricto sensu postgraduation programs.

In addition, it can be observed that $80.6 \%$ of the respondents have worked as teachers for more than
10 years. However, when teaching in stricto sensu postgraduation programs is considered, the predominant period of experience is up to five years, which is consistent with the fact that most stricto sensu postgraduation programs in the area of accounting sciences in Brazil have been created recently.

Table 3 reveals the results of the WTMST for each dimension studied in accordance with self-determination theory, considering the professors' work in stricto sensu postgraduation programs. The internal consistency of the instrument was measured using the Cronbach's alpha coefficient. The 15 items added to the questionnaire according to the model validated by Fernet et al. (2008) were analyzed, obtaining an alpha of $80.16 \%$, making it suitable for use in the research.

Table 3

Results of the Work Tasks Motivation Scale for Teachers (WTMST)

\begin{tabular}{|c|c|c|c|c|c|}
\hline Dimension & & Items & Mean & $\begin{array}{c}\text { Overall } \\
\text { mean }\end{array}$ & $\begin{array}{l}\text { Standard } \\
\text { deviation }\end{array}$ \\
\hline \multirow{3}{*}{$\begin{array}{l}\text { Intrinsic } \\
\text { motivation }\end{array}$} & 1 & Because it is pleasant to perform this task. & 5.54 & \multirow{3}{*}{5.81} & 1.24 \\
\hline & 2 & Because I find this task interesting to do. & 5.94 & & 0.98 \\
\hline & 3 & Because I like doing this task. & 5.97 & & 1.05 \\
\hline \multirow{3}{*}{$\begin{array}{l}\text { Identified } \\
\text { regulation }\end{array}$} & 4 & Because carrying out this task is important to me. & 6.05 & \multirow{3}{*}{6.04} & 1.00 \\
\hline & 5 & $\begin{array}{l}\text { Because this task allows me to achieve work objectives I consider } \\
\text { important. }\end{array}$ & 6.15 & & 1.01 \\
\hline & 6 & $\begin{array}{l}\text { Because I think this task is important for the academic success of my } \\
\text { students. }\end{array}$ & 5.92 & & 1.24 \\
\hline \multirow{3}{*}{$\begin{array}{l}\text { Introjected } \\
\text { regulation }\end{array}$} & 7 & Because if I don't carry out this task, I'll feel bad. & 3.42 & \multirow{3}{*}{3.01} & 1.76 \\
\hline & 8 & Because I'd feel guilty if I didn't do it. & 2.85 & & 1.73 \\
\hline & 9 & To not feel bad if I don't do it. & 2.76 & & 1.68 \\
\hline \multirow{3}{*}{$\begin{array}{l}\text { External } \\
\text { regulation }\end{array}$} & 10 & Because my job requires it. & 3.53 & \multirow{3}{*}{2.77} & 2.07 \\
\hline & 11 & Because the university obliges me to do it. & 2.36 & & 1.78 \\
\hline & 12 & Because I'm paid to do it. & 2.44 & & 1.82 \\
\hline \multirow{3}{*}{ Demotivation } & 13 & I don't know, I don't always see the relevance in carrying out this task. & 2.11 & \multirow{3}{*}{1.87} & 1.66 \\
\hline & 14 & I used to know why I was doing this task, but I no longer see the reason. & 1.71 & & 1.22 \\
\hline & 15 & I don't know, sometimes I don't see the point of it. & 1.78 & & 1.31 \\
\hline
\end{tabular}

Source: Elaborated by the authors using data from the research (2018).

According to the data presented in Table 3 and based on the 7-point agreement scale, it can be observed that the level of intrinsic motivation for the individuals analyzed was, on average, 5.81. Intrinsic motivation is considered to be the most self-determined type of motivation, since, according to Borges et al. (2017), it arises from performing a particular activity due to the individual's own satisfaction. That is, the professors teach in stricto sensu postgraduation because they feel fulfilled from performing this task. Rudnik (2012) states that it is necessary for an instrument for collecting data based on self-determination theory to take into consideration the existence of a tendency to transform values and external regulations into internal processes, provided they are ensured by the individual. This perhaps explains why the answers were concentrated in the highest levels of motivation.

Despite the high intrinsic motivation, it can be found that most of the individuals in the sample are extrinsically motivated. Of the three types of extrinsic motivation, working in stricto sensu postgraduation programs mainly arises from identified regulation (overall mean of 6.04), considering a higher level of self-determination in the 
extrinsic motivation, in which there is some interiorization of the motivation to perform the activity, even if the reason for doing it is external in origin (Leal et al., 2013). Extrinsic motivation, considering the level of identified regulation, shows that the teacher relates the activity to his/ her view with regards to duty performed, to his/her need for fulfillment and identification with the importance of this activity. In this case, the person accepts the external value as it is consistent with its importance, also involving a certain identification with the rule or the value. The task has already been internalized and the teacher barely differentiates it, or not at all, from his/her own rule (Rudnik, 2012).

The other dimensions - including demotivation presented lower levels, supporting the initial perception that there is high motivation of the professors to teach on stricto sensu postgraduation courses, from the perspective of self-determination theory.

Besides the questions related to the WTMST, the possible influences of other variables on the motivation of the individuals in the sample were also analyzed. The results are shown in Table 4.

Table 4

Analysis of the gender and institution type variables

\begin{tabular}{|c|c|c|c|c|c|}
\hline \multirow{2}{*}{ Dimension } & \multicolumn{2}{|c|}{ Mean } & \multicolumn{2}{|c|}{ Shapiro-Wilk (Prob>z) } & \multirow{2}{*}{$\begin{array}{l}\text { Wilcoxon-Mann-Whitney } \\
\text { (Prob }>\text { z) }\end{array}$} \\
\hline & Female & Male & Female & Male & \\
\hline Intrinsic motivation & 5.90 & 5.78 & 0.80 & 0.00 & 0.58 \\
\hline Identified regulation & 6.18 & 5.99 & 0.03 & 0.00 & 0.80 \\
\hline Introjected regulation & 3.23 & 2.94 & 0.42 & 0.00 & 0.27 \\
\hline External regulation & 2.83 & 2.75 & 0.45 & 0.00 & 0.63 \\
\hline Demotivation & 1.78 & 1.91 & 0.00 & 0.00 & 0.15 \\
\hline \multirow{2}{*}{ Dimension } & \multicolumn{2}{|c|}{ Mean } & \multicolumn{2}{|c|}{ Shapiro-Wilk (Prob>z) } & Wilcoxon-Mann-Whitney \\
\hline & Private & Public & Private & Public & $($ Prob>z) \\
\hline Intrinsic motivation & 6.40 & 5.72 & 0.00 & 0.00 & 0.00 \\
\hline Identified regulation & 6.36 & 5.99 & 0.46 & 0.00 & 0.28 \\
\hline Introjected regulation & 3.02 & 3.01 & 0.75 & 0.00 & 0.35 \\
\hline External regulation & 3.09 & 2.72 & 0.18 & 0.00 & 0.60 \\
\hline Demotivation & 1.56 & 1.92 & 0.37 & 0.00 & 0.29 \\
\hline
\end{tabular}

Source: Elaborated by the authors using data from the research (2018).

Table 4 presents the results of the gender and institution type variables for all the dimensions of self-determination theory. Considering that most of the data did not present a normal distribution, the Wilcoxon-Mann-Whitney test was chosen to identify significant differences between the groups. It can be perceived that the overall means of the intrinsic and extrinsic motivation dimensions are greater for the female professors; however, despite suggesting greater motivation among this group, this difference was not shown to be statistically significant. These results are consistent with those obtained by Vallerand et al. (1992) and Fernet et al. (2008), who observed that, in different life contexts, women report higher levels of self-determined motivation than men. Conversely, these results are in accordance with those found by Pizani et al. (2016), who explained the result as being due to the fact that the individuals are immersed in a common school environment. When analyzing the results according to gender, Lopes, Pinheiro, Silva, and Abreu (2015) also did not find any difference between genders and confirmed that, in both categories, this motivation type is, on average, high. Thus, hypothesis $\mathrm{H}_{1}$, which says that there is a difference between the motivation of female and male teachers, was rejected.

The influence of the institution type the professors are affiliated with was also analyzed, identifying higher levels of intrinsic and extrinsic motivation for the group of professors who work at private institutions. Yet, this result was shown to be statistically significant only for intrinsic motivation, demonstrating that the individuals who work at private teaching institutions feel more fulfilled teaching in stricto sensu postgraduation programs than those who work at public institutions, and this motivation arises independently of external factors, among which remuneration could be highlighted. In light of this result, hypothesis $\mathrm{H}_{2}$, which says that there is a difference in motivation between teachers from public institutions and from private institutions, was accepted only with regards 
to intrinsic motivation. This result raises an interesting question, since professors from private institutions are remunerated to teach in postgraduation, which does not occur at public institutions. Similarly, in the research of Cernev (2011), it was generally found that the teachers from both institution types presented a high level of motivation.
After analyzing the relationship between both gender and institution type and teacher motivation, the possible influence of age group, time teaching, and time in stricto sensu postgraduation on the motivation of the individuals in the sample was also analyzed. The results are presented in Table 5.

Table 5

Analysis of the age group, time teaching, and time in postgraduation variables

\begin{tabular}{|c|c|c|c|c|c|}
\hline Age group & $\begin{array}{c}\text { Intrinsic } \\
\text { motivation }\end{array}$ & $\begin{array}{l}\text { Identified } \\
\text { regulation }\end{array}$ & $\begin{array}{l}\text { Introjected } \\
\text { regulation }\end{array}$ & $\begin{array}{c}\text { External } \\
\text { regulation }\end{array}$ & Demotivation \\
\hline Up to 30 & 6.00 & 5.22 & 5.44 & 1.88 & 1.55 \\
\hline $31-40$ & 5.39 & 5.82 & 2.95 & 2.83 & 2.18 \\
\hline $41-50$ & 5.97 & 6.24 & 2.90 & 2.72 & 1.74 \\
\hline $51-60$ & 5.58 & 5.82 & 2.59 & 2.79 & 1.71 \\
\hline More than 60 & 6.31 & 6.23 & 3.67 & 3.08 & 2.15 \\
\hline \multicolumn{6}{|c|}{ Time teaching (years) } \\
\hline Up to 5 & 6.00 & 6.22 & 3.67 & 2.00 & 1.33 \\
\hline $6-10$ & 5.61 & 5.89 & 3.43 & 2.72 & 2.37 \\
\hline $11-15$ & 5.79 & 5.99 & 2.44 & 2.53 & 1.49 \\
\hline $16-20$ & 5.72 & 5.97 & 2.87 & 2.83 & 2.04 \\
\hline $21-25$ & 6.14 & 6.31 & 3.39 & 2.75 & 1.50 \\
\hline More than 25 & 5.91 & 6.12 & 3.20 & 3.14 & 1.97 \\
\hline \multicolumn{6}{|c|}{ Time in postgraduation (years) } \\
\hline Up to 5 & 5.75 & 6.02 & 2.79 & 2.51 & 1.67 \\
\hline $6-10$ & 5.98 & 6.20 & 3.11 & 3.09 & 2.17 \\
\hline $11-15$ & 5.85 & 5.97 & 3.85 & 3.03 & 1.85 \\
\hline $16-20$ & 5.67 & 5.89 & 2.63 & 3.19 & 2.15 \\
\hline $21-25$ & 6.33 & 6.33 & 5.33 & 4.33 & 3.33 \\
\hline More than 25 & 6.00 & 5.92 & 3.25 & 2.83 & 2.25 \\
\hline
\end{tabular}

Source: Elaborated by the authors using data from the research (2018).

Based on the data presented in Table 5, it can be observed that, for the individuals up to 30 years old and those older than 60 years old, motivation arises intrinsically. According to Huberman (1989), in the first three years of their careers, teachers are enthusiastic about working in the profession. This means they feel pleasure or satisfaction from carrying out their activities. At the end of their careers, this motivation may be high due to the feeling of duty performed, over the course of the path taken during their careers. For the individuals between 30 and 60, it is more related to identified regulation. Regarding time teaching, the motivation of the individuals analyzed was shown to be more related to identified regulation in any period of teaching. With relation to teaching in stricto sensu postgraduation, only the individuals who had worked in it for more than 25 years were shown to be intrinsically motivated. The others are motivated according to identified regulation, occurring when the identified regulations are totally assimilated, where external stimuli are understood to be a source and support for carrying out tasks. External regulations are internalized, with there being no coercion to regulate behavior; however, the external rule is still present (Ryan and Deci, 2000a). With regards to life cycle, it is verified that, independently of the stage of the career, the professors choose postgraduation due to their personal values, even if it is an activity that is not of interest to them (Huberman, 1989).

The chi-squared test was conducted was the aim of analyzing the association between the levels of motivation and age group, time teaching, and time teaching in stricto sensu postgraduation. According to the results obtained ( $\mathrm{p}$-value $=0.99$ for the three tests), none of the three variables was shown to be statistically significant, demonstrating that, in relation to the sample researched, age group and time teaching and time in stricto sensu 
postgraduation are not associated with teacher motivation. Thus, hypothesis $\mathrm{H}_{3}$, which says that there is a relationship between teacher motivation and age group, was rejected; hypothesis $\mathrm{H}_{4}$, which says that there is a relationship between teacher motivation and time teaching, was rejected; and hypothesis $\mathrm{H}_{5}$, which says that there is a relationship between teacher motivation and time teaching in stricto sensu postgraduation, was also rejected.
In addition to the items analyzed, in accordance with the study by Fernet et al. (2008), in this research four questions were included, with the aim of identifying the professors' motivation in relation to status and obtaining financial resources from teaching in stricto sensu postgraduation programs. The results are presented in Table 6.

Table 6

Results of the Work Tasks Motivation Scale for Teachers (WTMST) - Additional questions

\begin{tabular}{|c|c|c|c|c|}
\hline & Item & Mean & Standard deviation & Coefficient of variation \\
\hline 16 & $\begin{array}{l}\text { I feel that performing this task gives me a certain status at the } \\
\text { university where I lecture. }\end{array}$ & 4.99 & 1.68 & 0.34 \\
\hline 17 & $\begin{array}{l}\text { Working in stricto sensu postgraduation enables me to have } \\
\text { privileges among the other researchers. }\end{array}$ & 3.87 & 1.91 & 0.49 \\
\hline 18 & $\begin{array}{l}\text { I perceive that I stand out at academic events because I work in } \\
\text { stricto sensu postgraduation. }\end{array}$ & 4.00 & 1.89 & 0.47 \\
\hline 19 & $\begin{array}{l}\text { I am in postgraduation since it enables me to have easier access } \\
\text { to financial resources through research projects funded by support } \\
\text { agencies. }\end{array}$ & 3.76 & 1.96 & 0.52 \\
\hline
\end{tabular}

Source: Elaborated by the authors using data from the research (2018).

Of the questions added, the professors analyzed presented a higher level of agreement with relation to the status that can be obtained from teaching in stricto sensu postgraduation programs. Among them, the one that obtained the highest mean, "I feel that performing this task gives me a certain status at the university where I lecture", confirms this fact directly, demonstrating that, more than access to financial resources, teaching in these programs may be motivated by the prestige that it brings to the professors in relation to their peers. In addition, the answer to this same question is less dispersed around the mean, which can be observed by the coefficient of variation (0.54), indicating greater consistency among the respondents with regards to this question.

Costa and Melo (2011) state that, concentrating on a set of vanities, it is among the teaching staff where success, prestige, and recognition is obtained and, for this reason, even unconsciously, professionals subject themselves to informal impositions from their peers. As they are immersed in a tight organizational system of day-to-day control, power relations are established through triangulations with other bodies, notably due to the influence over students and the connections with various institutional interest groups.

Vanity may be considered a structural characteristic that is inherent to human beings. In it would reside the basis for the researcher social being's identification with the institutional culture; based on it there would be pleasure in achieving the targets set by funding agencies and in producing particular knowledge induced by the funding to dictate what should be produced by the researchers (Silva, Ferreira \& Kato, 2013).

Note, also, that the question regarding the teacher working in postgraduation with the aim of gaining access to financial resources was the one that had the lowest mean and highest coefficient of variation. This result may indicate that this would be the reason that matters the least to the professors when deciding to teach in postgraduation. In addition, a greater variation is verified between the respondents' scores.

After analyzing the 34 valid (and facultative) answers for the open question related with other reasons that motivated the professors' teaching in the stricto sensu postgraduation program at the institution where they work, it was possible to identify some factors that motivate and demotivate the professors when teaching in stricto sensu postgraduation programs. Among the motivational factors most mentioned in the answers is the possibility of contributing to the training and development of researchers, professionals, people, teachers, and also of the accounting profession. Therefore, the motivation would derive from the expectation of being able to contribute to the training both of other individuals and the development of the profession. Another factor mentioned is the greater possibility of developing research, being in contact with more in-depth discussions, keeping up-to-date, and not slipping into the demotivational routine of teaching. These answers are related to the research aspect, which is highly 
present in stricto sensu postgraduation programs. The question of demotivation for teaching activities can be confirmed in the research of Cernev (2011), whose results demonstrated that the motivation to work as a teacher decreases with the passing of time. In contrast, besides the answers that addressed motivational factors, some professors indicated demotivational factors in relation to teaching in these programs. The most recurrent factor was excess pressure and demands to publish articles, which are imposed by Capes and reinforced by the programs in general.

In general, the results of this research indicate a high level of intrinsic and extrinsic motivation due to identified regulation, demonstrating that the professors analyzed identify with the activities developed. The results indicate that they feel fulfilled from being able to contribute to the development of individuals and of the accounting profession.

\section{CONCLUDING REMARKS}

Studying motivation is important and highly rated due to the consequences that it produces. Research on the subject is relevant for individuals whose role is related to mobilizing other individuals to act, such as in the area of teaching, which is directly connected with training people, with developing the profession, and with the quality of teaching. Over the course of their careers, teachers tend to reduce their commitment and motivation in relation to teaching. With this, they seek support and opportunities in order to keep up-to-date and motivated.

Individuals have various levels of motivation and, for this reason, self-determination theory was used in this research with the aim of analyzing the motivational factors that lead professors from the area of accounting sciences to teach in stricto sensu postgraduation. The research was conducted using an electronic questionnaire, obtaining 108 answers.

Based on the results, the professors who answered the survey are generally men who work in the public teaching sector aged between 41 and 50 and who have been teaching for more than 10 years; however, they have been teaching in stricto sensu postgraduation programs for up to five years, on average.

The results obtained based on the WTMST showed a high level of intrinsic motivation. However, most of the individuals in the sample are extrinsically motivated through identified regulation, which is the highest level of self-determination of extrinsic motivation, in which the individual perceives some interiorization of the motivation to perform the activity, even if the reason for doing it is external in origin.

Based on these findings, this research contributes to identifying the profile of the motivation of postgraduation professors. Given that this is an environment with important professional opportunities, but also one involving great challenges, this study helps in obtaining a diagnostic analysis of the aspects that may be related to teacher motivation. Based on this analysis, teachers can cater to their strengths, potential, and needs, making them able to establish goals and define personal and professional objectives through which their level of motivation will be determined.

Understanding the motivation of accounting postgraduation professors, as well as identifying what their behavior is in this sense, helps in the elaboration and implementation by postgraduation programs of mechanisms that contribute to improving their motivation. More motivated professors can develop, in a more pleasurable and efficient way, their activities within the area of research, teaching, and extension, since they will seek an objective in carrying these out.

Studying the commitment of teachers using this approach is essential, since the existence of motivation in the teaching-learning process is directly reflected in the behavior of the individuals involved in the educational process. More motivated teachers will better develop the teaching-learning process, raising awareness among students of the object of knowledge in a genuine way. In this context, this research results in the execution of different possibilities and amplitudes of its object of study, contributing to significant transformations in the postgraduation environment.

In an environment in which the demand for knowledge, training, productivity, and pedagogical and scientific demand is growing, teachers can seek personal alternatives that provide them with a path towards self-fulfillment. Thus, motivating behavior constitutes one of the aspects that compose the personal and interpersonal quality that cooperates with a personalized, motivating, and successful teaching practice.

In addition, the answers given by the professors regarding the possible additional motivations demonstrate that, more than access to financial resources, teaching in these programs may be motivated by the prestige that it brings in relation to peers. The main factors that motivate the professors are related both with the possibility of 
contributing to the training of other individuals and shaping the profession and with developing research and avoiding slipping into the demotivational routine of teaching.

From the analysis of the answers to this question, interesting observations can be made. Since the professors demonstrated, on average, a high level of motivation and taking into account the unfavorable backdrop for developing research, what factors could be leading the professors to teach in these programs, since this considerably increases their workload, without alternating their financial return? The answer may be related to the status obtained from such work. As observed in the results of other studies, this is an environment in which signs of vanity are observed and where recognition and appreciation from peers are important, demonstrating that, despite teaching in postgraduation not being objectively attractive, the status achieved among their peers means the professors feel motivated to work in this area.

This research presents as a limitation the fact that the sample is not random. Therefore, the results cannot be generalized for all professors who work in Brazilian stricto sensu postgraduation programs in the area of accounting sciences. With this, it is recommended that the procedures adopted are applied in other studies, in different samples, so that the results obtained can be compared with those from different contexts. It is also suggested that studies are conducted that analyze the relationship between the motivation of teaching staff and the student body, since these are closely linked during the stricto sensu postgraduation course.

\section{REFERENCES}

Barreto, M. O., \& Martinez, A. M. (2007). Possibilidades criativas de professores em cursos de pós-graduação stricto sensu. Estudos de Psicologia, 24(4), 463-473.

Biazus, C. A. (2004). Sistema de fatores que influenciam o aluno a evadir-se dos cursos de graduação na UFSM e na UFSC: Um estudo no curso de ciências contábeis (Doctoral Thesis). Universidade Federal de Santa Catarina, Florianópolis.

Bizarria, F. P. A., Carneiro, T. C. J., Silva, M. A., \& Tassigny, M. M. (2016). Escala de Motivação Acadêmica: Validade no contexto da educação à distância em curso de administração pública. Revista Capital Científico, 14(4), 75-91.

Borges, M. S., Miranda, G. J., \& Freitas, S. C. (2017). A teoria da autodeterminação aplicada na análise da motivação e do desempenho acadêmico discente do curso de ciências contábeis de uma instituição pública brasileira. Revista Contemporânea de Contabilidade, 14(32), 89-107.

Cernev, F. K. (2011). A motivação de professores de música sob a perspectiva da teoria da autodeterminação (Master's Dissertation). Universidade Federal do Rio Grande do Sul, Porto Alegre.

Coordenação de Aperfeiçoamento de Pessoal de Nível Superior. Diretoria de Avaliação (2017). Avaliação quadrienal. Retrieved from https://docs.google.com/viewer?a=v\&pid=sites\&srcid=Y2FwZXMuZ292LmJyfGF2YWxpYWNhby1xdWFkcmllbmFsfGd4OjExZmJlMmIxY2JkZjgyZjc.

Costa, M., \& Melo, M. C. D. O. L. (2011). Novos olhares sobre as relações de poder entre docentes na gestão universitária. In Anais do IX Colóquio Internacional sobre Gestão Universitária na América do Sul (p. 1-15). Florianópolis, SC.

Davoglio, T. R., Santos, C., \& Spagnolo, B. S. (2017). Motivação para a permanência na profissão: A percepção dos docentes universitários. Psicologia Escolar e Educacional, 21(2), 175182.

Deci, E. L. (1971). Effects of externally mediated rewards on intrinsic motivation. Journal of Personality and Social Psychology, 18(1), 105-115.
Deci, E. L., \& Ryan, R. M. (1985). Intrinsic motivation and selfdetermination in human behavior. New York, NY: Plenum.

Durso, S. O., Cunha, J. V. A., Neves, P. A., \& Teixeira, J. D. V. (2016). Fatores motivacionais para o mestrado acadêmico: Uma comparação entre alunos de ciências contábeis e ciências econômicas à luz da teoria da autodeterminação. Revista Contabilidade \& Finanças, 27(71), 243-258.

Fernet, C., Senécal, C., Guay, F., Marsh, H., \& Dowson, M. (2008). The Work Tasks Motivation Scale for Teachers (WTMST). Journal of Career Assessment, 16(2), 256-279.

França, C. F. F., Rodrigues, J. G., Mariano, L. C., Junior, Santos, W. L. M., \& Campos, L. A. S. (2012). Análise sobre a motivação dos professores de educação física escolar e a profissionalização da docência. Coleção Pesquisa em Educação Física, 11(1), 71-70.

Guimarães, S. E. R., \& Boruchovitch, E. (2004). O estilo motivacional do professor e a motivação intrínseca dos estudantes: Uma perspectiva da teoria da autodeterminação. Psicologia: Reflexão e Crítica, 17(2), 143-150.

Herdeiro, R., \& Silva, A. M. C. (2014). As políticas educativas e a motivação dos professores para o trabalho docente. In Flores, M. A., Coutinho, C., \& Lencastre, J. A. (Org.). Atas do congresso Formação e trabalho docente na sociedade da aprendizagem, organizado no âmbito da International Study Association on Teachers and Teaching (ISATT) e do Centro de Investigação em Estudos da Criança (CIEC). Braga: CIEC, Uminho.

Huberman, M. (1989). La vie des enseignants. Évolution et bilan d'une profession. Neuchâtel: Delachaux \& Niestlé.

Iaochite, T. R., Costa Filho, R. A., Matos, M. M., \& Sachimbombo, K. M. C. (2016). Autoeficácia no campo educacional: revisão das publicações em periódicos brasileiros. Psicologia Escolar e Educacional, 20(1), p. 45-54.

Larocca, P., \& Girardi, P. (2011). Trabalho, satisfação e motivação docente: Um estudo exploratório com professores da educação básica. In Anais do X Congresso Nacional de 
Educação - EDUCERE. I Seminário Internacional de Representações Sociais, Subjetividade e Educação - SIRSSE (p. 1-17). Curitiba, PR.

Leal, E. A., Miranda, G. J., \& Carmo, C. R. S. (2013). Teoria da autodeterminação: Uma análise da motivação dos estudantes do curso de ciências contábeis. Revista Contabilidade \& Finanças, 24(62), 162-173.

Lira, M., \& Silva, V. P. G. (2015). Motivação intrínseca vs. motivação extrínseca: A aplicação da Escala WPI no contexto do setor público português. Revista de Gestão, Finanças e Contabilidade, 5(4), 171-195.

Lopes, L. M. S., Pinheiro, F. M. G., Silva, A. C. R. D., \& Abreu, E. S. D. (2015). Aspectos da motivação intrínseca e extrínseca: Uma análise com discentes de ciências contábeis da Bahia na perspectiva da teoria da autodeterminação. Revista de Gestão, Finanças e Contabilidade, 1(1), 21-39.

Machado, A. C. T. A., Guimarães, S. E. R., \& Bzuneck, J. A. (2006). Estilo motivacional do professor e a motivação extrínseca dos estudantes. Semina: Ciências Sociais e Humanas, 27(1), 3-13.

Martins, G. A., \& Theóphilo, C. R. (2009). Metodologia da investigação científica para as ciências sociais aplicadas $\left(2^{\text {nd }}\right.$ ed.) São Paulo, SP: Atlas.

Pizani, J., Barbosa-Rinaldi, I. P., Miranda, A. C. M., \& Vieira, L. F. (2016). (Des) motivação na educação física escolar: Uma análise a partir da teoria da autodeterminação. Revista Brasileira de Ciências do Esporte, 38(3), 259-266.

Rudnik, L. (2012). Avaliação da motivação do professor para tarefas específicas do seu trabalho: Adaptação e validação de um instrumento (Master's Dissertation). Universidade Estadual de Londrina, Londrina.
Ryan, R. M., \& Deci, E. L. (2000a). Intrinsic and extrinsic motivations: Classic definitions and new directions. Contemporary Educational Psychology, 25(1), 54-67.

Ryan, R. M., \& Deci, E. L. (2000b). Self-determination theory and the facilitation of intrinsic motivation, social development, and well-being. American Psychological Association, 55(1), 68-78.

Sá, C. S. S., \& Santos, W. L. P. (2016). Motivação para a carreira docente e construção de identidades: O papel dos pesquisadores em ensino de química. Química Nova, 39(1), 104-111.

Silva, J. R., Júnior, Ferreira, L. R., \& Kato, F. B. G. (2013). Trabalho do professor pesquisador diante da expansão da pós-graduação no Brasil pós-LDB. Revista Brasileira de Educação, 18(53), 435-499.

Silva, A., Pletsh, C. S., \& Biavatti, V. T. (2015). Reação motivacional docente do curso de graduação em ciências contábeis sob a perspectiva da teoria atribucional. Contabilidad y Negocios, 10(20), 70-82.

Sobral, D. T. (2003). Motivação do aprendiz de medicina: Uso da Escala de Motivação Acadêmica. Psicologia: Teoria e Pesquisa, 19(1), 25-31.

Vallerand, R. J., Blais, M. R., Brière, N. M., \& Pelletier, L. G. (1989). Construction and validation of the Echelle de Motivation en Education (EME). Canadian Journal of Behavioral Sciences, 3(21), 323-349.

Vallerand, R. J., Pelletier, L. G., Blais, M. R., Brière, N. M., Senécal, C., \& Vallières E. F. (1992). The academic motivation scale: A measure of intrinsic, extrinsic, and a motivation in education. Educational and Psychological Measurement, 52(4), 1003-1017. 